\title{
T-wave inversions with a difference
}

\section{Anandaroop Lahiri, Anoop George Alex, Oommen K George}

Department of Cardiology, Christian Medical College and Hospital, Vellore, Tamil Nadu, India

\section{Correspondence to}

Dr Anandaroop Lahiri, anandaroop_lahiri@yahoo.com

Accepted 17 March 2016

\section{DESCRIPTION}

A middle-aged patient presented to the acute chest pain unit (ACPU), due to retrosternal chest discomfort with bradycardia at 59 beats per minute. The electrocardiograph (ECG) showed sinus bradycardia with diffuse deep T-wave inversions. Troponin $\mathrm{T}$ was $38.76 \mathrm{pg} / \mathrm{mL}$ (normal $\leq 14 \mathrm{pg} / \mathrm{mL}$ ). Suspecting an acute coronary syndrome, the patient underwent coronary angiography, which was, surprisingly, normal. Serum thyroid stimulating hormone level, sent as part of routine biochemistry, was $304 \mu \mathrm{IU} / \mathrm{mL}$ (normal $\leq 4.5 \mu \mathrm{IU} / \mathrm{mL}$ ) with low free thyroxine confirming severe hypothyroidism.
On retrospective examination of the ECG (figure $1)$, we noticed low voltage QRS complexes and QTc prolongation (640 ms by Bazett's formula). Another strip (figure 2) revealed polymorphic ventricular premature contractions with varying axes, couplets and triplets with varying QRS voltages.

Interestingly, all these electrocardiographic findings have been reported in patients with hypothyroidism, including Torsades de Pointes. ${ }^{1}{ }^{2}$ The patient was started on replacement thyroxine, reminding us lucidly of this uncommon cause of T-wave inversions on the ECG and the need for routine thyroid evaluation.

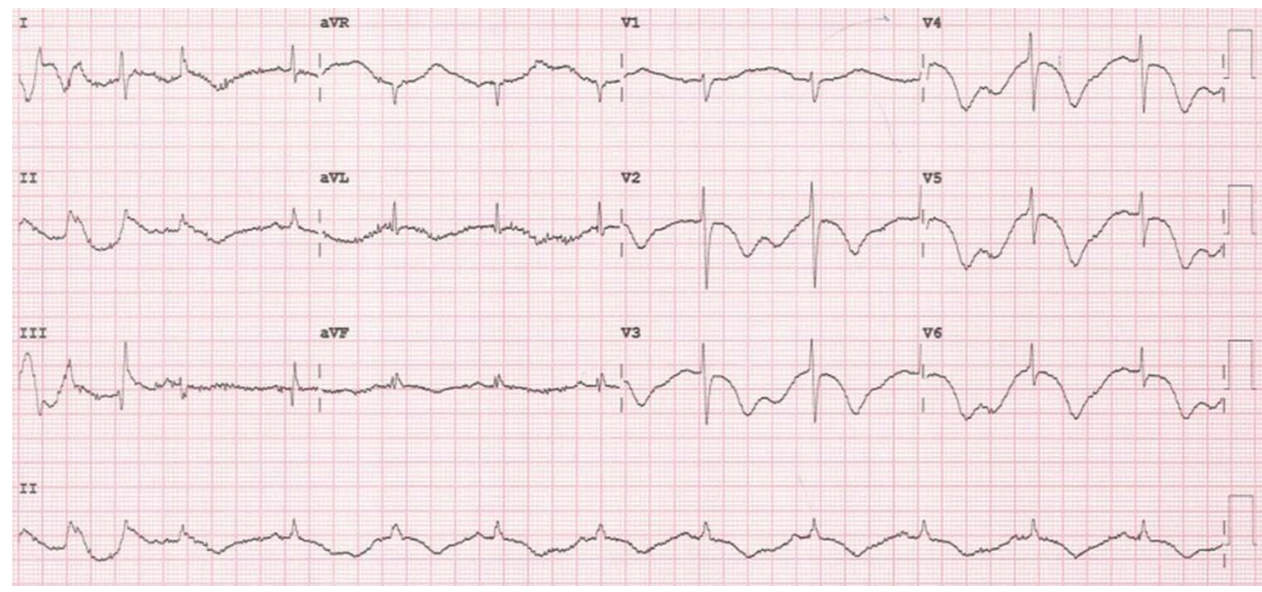

Figure 1 Low voltage QRS complexes in limb leads and prolonged QTC.

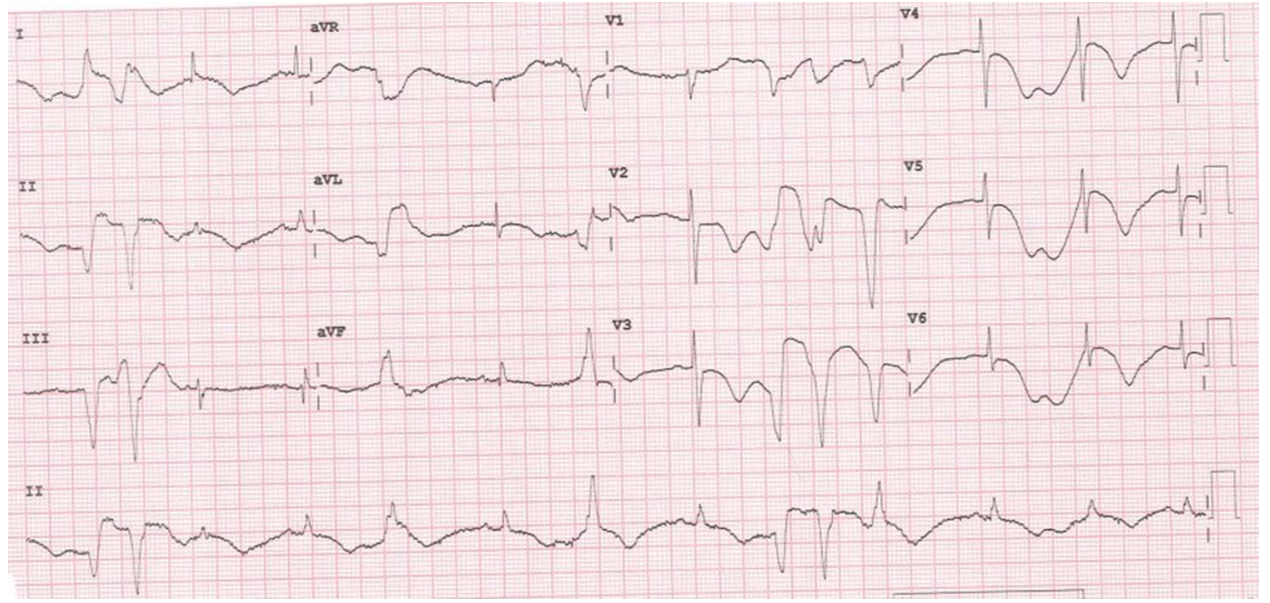

Figure 2 Polymorphic ventricular contractions-one couplet and one triplet.
To cite: Lahiri A, Alex AG, George OK. BMJ Case Rep Published online: [please include Day Month Year] doi:10.1136/bcr-2015-

214307
CrossMark 


\section{Learning points}

- Hypothyroidism, apart from being associated with sinus bradycardia and low voltage QRS complexes, can also manifest as prolongation of action potential duration, prolongation of QTc interval and even malignant arrhythmias such as Torsades de Pointes.

- In view of the myriad presentations of hypothyroidism and its associated manifestations pertaining to the cardiovascular system, it may be prudent to screen for it routinely by biochemical evaluation, irrespective of the presence or absence of classical clinical features.
Contributors AL worked up the case and wrote the case report. AGA conducted the literature search and formatted the images. OKG reviewed the entire report and critically appraised it with his comments, which were incorporated by AL.

Competing interests None declared.

Provenance and peer review Not commissioned; externally peer reviewed.

\section{REFERENCES}

1 Shojaie M, Eshraghian A. Primary hypothyroidism presenting with Torsades de pointes type tachycardia: a case report. Cases J 2008;1:298.

2 Schenck JB, Rizvi AA, Lin T. Severe primary hypothyroidism manifesting with torsades de pointes. Am J Med Sci 2006;331:154-6.

Copyright 2016 BMJ Publishing Group. All rights reserved. For permission to reuse any of this content visit http://group.bmj.com/group/rights-licensing/permissions.

BMJ Case Report Fellows may re-use this article for personal use and teaching without any further permission.

Become a Fellow of BMJ Case Reports today and you can:

- Submit as many cases as you like

- Enjoy fast sympathetic peer review and rapid publication of accepted articles

- Access all the published articles

- Re-use any of the published material for personal use and teaching without further permission

For information on Institutional Fellowships contact consortiasales@bmjgroup.com

Visit casereports.bmj.com for more articles like this and to become a Fellow 